\title{
Tape Casting Technique for Fabrication of Piezoelectric Ceramics and Other Multilayered Devices-A Review
}

\author{
Prasanta Kumar Panda*, Benudhar Sahoo \\ Materials Science Division, CSIR - National Aerospace Laboratories, PB 1779, Kodihalli, Bengaluru-560017, India \\ *Corresponding author: Prasanta Kumar Panda, E-mail: pkpanda@nal.res.in
}

DOI: $10.37155 / 2717-526 \mathrm{X}-0302-1$

\begin{abstract}
Tape casting is a preferred technique for fabrication of micron sized thin sheets and multi-layered stacks. This technique can be used for all types of materials available in powder form. Therefore, this is a versatile technique used for fabrication of capacitors, piezoelectric multi-layered stacks, functional gradient materials, low temperature co-fired ceramics (LTCC) and so on involving all types of metals, ceramics and polymers. In this article, tape casting method is reviewed including the slurry preparation and role of various ingredients. This technique is widely used for fabrication of piezoelectric multi-layered stacks in order to reduce the "driving voltage" up to few volts for micro-meter sized thin layers. The preparation methodology of slurry making for tape casting and role of various ingredients are discussed in detail including multi-layered fabrication of devices. Typical tape casting examples of lead zirconate titanate (PZT) and barium strontium zirconate titanate (BSZT) lead free piezo materials are also presented. Various application of tape casting in recent years has been reviewed.
\end{abstract}

Keywords: Tape casting; Slurry; Binder; Plasticizer; Multilayered stack

\section{Introduction}

Tape casting is a manufacturing technique for the production of thin sheets any material available in powder form according to R. E. Mistler. ${ }^{[1]}$ This includes all types of products such as metallic electrodes, organic lithium polymer battery components, ceramic substrates etc. ${ }^{[2]}$ In recent years, the thrust is mainly for production and use of thin and miniaturized products such as LTCC, multi-layered (ML) stacks, thin substrates, functionally gradient materials (FGM) and so on, wherein, micrometre sized thin tapes are used. Therefore, tape casting is the preferred technique used for fabrication of the above devices. ${ }^{[3]}$
Tape casting was originally developed in the mid1940s during the Second World War by Glenn Howatt who is universally regarded as the "father" of tape casting. ${ }^{[4]}$ His work includes manufacturing of thin piezoelectric materials by tape casting as a replacement to natural mica in capacitor devices. Howatt was granted the first patent on this technique wherein it described "forming ceramic materials into flat plates, especially useful in the electric and radio fields.". ${ }^{[5]}$ It was later improved in the mid-1950s by John L. Park, Jr. ${ }^{[6]}$ of American Lava Corporation introducing a moving polymer carrier as a casting surface and started producing the ceramic tapes on continuous 
basis. In 1947, Howatt established a manufacturing facility (Metuchen, N.J, USA) based on tape casting technology for fabrication of capacitors and played a key role in growth of this technique. ${ }^{[4]}$ There are a lot of changes/improvements in the tape casting technique in order to cope up with the requirements of growing electronic and other industries. A brief summary on development of the tape casting process and products is presented in Table 1.

Table 1. Development of Tape Casting Process and Products [1-6]

\begin{tabular}{|c|c|}
\hline Year & Developments \\
\hline 1944 & Tape-casting machine was fabricated \\
\hline 1947 & $\begin{array}{c}\text { First Publication on tape casting by Glen Howatt } \\
\text { and co workers }\end{array}$ \\
\hline 1952 & $\begin{array}{c}\text { First Patent on tape casting published by Glen } \\
\text { Howatt. }\end{array}$ \\
\hline $1952-54$ & $\begin{array}{c}\text { Development and production of ceramic tapes at } \\
\text { American Lava Corp. }\end{array}$ \\
\hline 1954 & $\begin{array}{l}\text { JL Park invented continuous tape casting using an } \\
\text { impervious polymer carrier and a doctor blade. }\end{array}$ \\
\hline $1958-59$ & $\begin{array}{c}\text { Development of multilayered ceramics using tape } \\
\text { casting }\end{array}$ \\
\hline 1960 & $\begin{array}{c}\text { Lamination process of tape-cast ceramics to form } \\
\text { multilayers. }\end{array}$ \\
\hline 1967 & Tape casting of thin film aluminum oxide \\
\hline 1967 & $\begin{array}{c}\text { Multilayer laminate for computer application } \\
\text { reported by IBM }\end{array}$ \\
\hline $1980 \mathrm{~s}-90 \mathrm{~s}$ & $\begin{array}{l}\text { Maturing of tape casting technology and its } \\
\text { application to many new fields such as fuel cells, } \\
\text { capacitor industry etc. }\end{array}$ \\
\hline 1992 & $\begin{array}{l}\text { Fabrication of 3D-objects and rapid prototyping of } \\
\text { tape casting technology by Lone Peak Engineering. }\end{array}$ \\
\hline 1996 & $\begin{array}{l}\text { Tape thickness of } 5-\mu \mathrm{m} \text { was fabricated in Japan } \\
\text { for the } 1^{\text {st }} \text { time. }\end{array}$ \\
\hline 1997 & $\begin{array}{l}\text { Continuous fabrication of thin tape of } 5-\mu \mathrm{m} \text { thick } \\
\text { at industrial level for MLCC application. }\end{array}$ \\
\hline 1998 & $\begin{array}{l}\text { Report of fabrication of } 3 \mu \mathrm{m} \text { thick tape by } \\
\text { several researchers }\end{array}$ \\
\hline $\begin{array}{l}2000- \\
2020\end{array}$ & $\begin{array}{l}\text { Optimization of various aqueous and non-aqueous } \\
\text { based slurries for tape casting and applications to } \\
\text { various industries. Fabrication of PZT ML stacks, } \\
\text { Amplified piezo actuators by tape casting. }\end{array}$ \\
\hline
\end{tabular}

Recently, a variety of multi-layered (ML) ceramics were prepared by tape casting technique with superior properties and better performance. These ML devices were widely used in various filed such as aerospace, electronics, communication, biomedical, automotive industries, metallic materials, power electronics etc. in the form of actuators, sensors and capacitors. Design of these multi-layered structures are very much important for improving performance of the device as a whole and the ceramic materials in particular. ${ }^{[7]}$

\subsection{Method of Tape Casting}

In this method a stable slurry of a ceramic powder is prepared using an aqueous or non-aqueous liquid and a dispersant is mixed for the stability of the ceramic powder in the solution. Binders and plasticizers are added for providing strength and flexibility to green tapes. These constituents are generally added in different stages to obtain a uniform and well dispersed slurry. Once the suspension is ready, it is cast on a flat surface. ${ }^{[8,9]}$ The thickness of the prepared tape depends on many parameters such as (i) gap between the doctor's blade and the carrier plastic film, (ii) speed of the plastic carrier, (iii) initial viscosity of the suspension and (iv) drying shrinkage of the tape. The cast tape is then dried slowly to avoid surface cracks till the solvent evaporates. The required shapes/devices are fabricated using green tapes, finally sintered to hard and dense ceramic components.

\subsection{Advantages of Tape Casting}

The main advantage of this process is fabrication of large, thin and flat ceramic or metallic parts which are virtually impossible to prepare by pressing or extrusion method. The flexibility of green tape helps in easy punching or cutting into various sizes and shapes required for fabrication of multilayered ceramic devices. ${ }^{[2]}$

\section{Various Components of Tape Casting}

\subsection{Preparation of Slurry}

Preparation of a homogeneous, high solid loading, well dispersed slurry with optimal viscosity and optimal quantities of solvent(s), binders, dispersants and plasticizers holds the key for the successful fabrication of defect free high green density tapes. ${ }^{[10]}$ The effect of various components in the preparation of the slurry is discussed below.

\subsection{Ceramic Powder}

Ceramic powder is the main constituent for slurry making. Its characteristics play a very important role in the stability and homogeneity of the slurry. The powder must be very fine and their particle size distribution should be in the narrow range. ${ }^{[11]}$ These parameters are critical for the fabrication of thin tapes. Otherwise, 
the cast tapes will have defects such as low green and sintered densities, increase in porosity and defects which ultimately leads to the degradation of electronic properties. In general, sub-micron sized spherical powders prepared by various chemical routes or by attrition milling are used.

\subsection{Solvent}

The solvent acts a vehicle for the slurry, which carries the different components, some of them by dissolving and the others by dispersing resulting formation of a homogeneous slurry. The solvent should be non-reactive with the ceramic powder with good wetting characteristics. ${ }^{[12,13]}$ The solvent can be either aqueous or non-aqueous. The aqueous tape casting is very cheap and environmentally friendly, however, it is very difficult to get defect free tapes due to their susceptibility to drying and environmental conditions. Non-aqueous solvents have advantages such as a low viscosity, a low boiling point, low surface tension, low dielectric constant, and a high vapor pressure and evaporate easily compared to water. Thus, they are widely used in tape casting in spite of the drawbacks such as inflammability and toxicity. The use of azeotropic mixtures compared to single solvent system helps in improving the organic solubility, prevents preferential volatilization and polymeric surface skin formation. $^{[14]}$

\subsection{Dispersant/Wetting Agent}

Dispersion of the slurry is critical for tape casting. A well dispersed slurry results in high solid loading and low slurry viscosity which ultimately reflects in high packing density and homogeneity. The slurry should contain optimum amount of the dispersant, which could be arrived by trial and error method because the excessive amount might result in sticking of the particles, hence, would increase the viscosity. ${ }^{[15]}$ The order of addition of dispersant, binder and plasticizer is important in order to achieve well dispersed slurry. The dispersant has to be added before the addition of binders and plasticizers, so that ceramic particles was fully coated by dispersant and keeps them in a state of suspension in the slurry. For maximum effectiveness, the dispersant must have access to each particle surface. If the binders and plasticizers are added first, a coating of the organics would hinder the action of dispersants.

\subsection{Binder}

Binders are added to the slurry to improve the green strength required for handling of the tapes. It remains in the tape forming organic bridges between particles resulting in a strong adhesion after solvent evaporation. Another important role of the binder is that it helps in bonding the green sheets together during the thermocompression step of the lamination process. ${ }^{[16-18]}$ It also improves wetting and delays settling of the powder particles. Some of the properties the binder must have are: (i) high molecular weight, (ii) an effective burn out without residue, (iii) a low glass transition temperature etc. Organic binders provide green strength and plasticity to the ceramic powder. The ash-content of binders are also very important as zero level of ash content imparts excellent properties to ceramic materials while its higher level affects the microstructures and hence performance. Polyvinyl alcohol (PVA), polyethylene glycol (PEG) and polyvinyl pyrrolidone (PVP) show zero level of ash content at $600^{\circ} \mathrm{C}$.

\subsection{Plasticizer}

Plasticizers induce flexibility to the green tape required for fabrication of complex and multilayered components. An appropriate combination of binder and plasticizers are required to provide the binding and flexibility to the tapes for easy handling and fabrication of complex shapes. ${ }^{[19]}$ In some cases, a dual plasticizer is beneficial.

\section{Stages in the Preparation of Slurry}

Most tape casting processes start with a milling process which can be broken into two stages-In the first step only the dispersant is added to the solvent and the ceramic powder. In the second step, the plasticizers and binders are added. Adding the plasticizers to the mill before the addition of the binder aids in the dissolution of the binder into the overall slurry.

\section{1. $1^{\text {st }}$ Stage Milling}

In this stage the solvent, the powder, the dispersant and the grinding media are mixed. The order of mixing the ingredients is very much important for preparation of well optimized slurry. The sequence followed is mixing of the dispersant in the solvent first, then the grinding media and finally addition of the powder. The bottle is tightly closed 
and kept for milling about 12-24 h. In this stage, the agglomerates and large particles were brakes and helps in equal distribution of the dispersant on the surfaces of the individual particles.

\section{2. $2^{\text {nd }}$ Stage Milling (Addition of Binder and Plasticizer)}

In this stage the plasticizers are added first followed by the binder as the binder is found to be more soluble in plasticizer compared to solvent system. The standard practice is to continue milling for 12-24 h. The next step involves the removal of any air bubbles in the slurry by slow rotation or stirring accompanied by the application of vacuum in a closed container. This process separates the unwanted air bubbles as well as agglomerates if any in the slurry which improves the surface aspect of the tapes by decreasing the extrinsic sources of cracks.

Table 2. Commonly Used Components in Aqueous Tape Casting of Ceramic Powders [1, 17, 23].

\begin{tabular}{|c|c|c|c|}
\hline Solvents & Dispersants & Binders & Plasticizers \\
\hline -Water & $\begin{array}{l}\text {-Ammonium polyacrylate } \\
\text {-Polycarboxylate ammonium salt } \\
\text { - Nonionic octyl phenoxyethanol } \\
\text {-Amino hydroxyl salt of carboxylic acid } \\
\text {-Polymethacrylic acid } \\
\text {-Ammonium salt of polymethyl acrylic acid } \\
\text {-Amino alcohol } \\
\text { - Sodium hexa meta phosphate } \\
\text {-Polyethyleneimine } \\
\text {-Ammonium polycarboxylate based } \\
\text { polyelectrolyte }\end{array}$ & $\begin{array}{l}\text {-Acrylic polymer } \\
\text {-Ethylene Oxide polymer } \\
\text {-Hydroxyethyl cellulose } \\
\text { - Methyl cellulose } \\
\text {-Poly(vinyl alcohol) } \\
\text {-Acrylic copolymer latex } \\
\text {-Polyurethane } \\
\text {-Poly (vinyl acetate) dispersion } \\
\text {-Styrene-butadiene rubber emulsion } \\
\text {-Carboxymethyl cellulose } \\
\text { - Gelatin } \\
\text {-Latex emulsions }\end{array}$ & $\begin{array}{l}\text {-Benzyl butyl phthalate } \\
\text {-Dibutyl phthalate } \\
\text {-Ethyltoluene sulfonamides } \\
\text { - Glycerine } \\
\text {-Poly(ethylene) glycol } \\
\text { - Tri-n-butyl phosphate } \\
\text {-Poly(propylene glycol) } \\
\text { - Triethylene glycol } \\
\text {-Ethylene glycol } \\
\text { - Glycerol }\end{array}$ \\
\hline
\end{tabular}

Rheological behavior of water based slurry is very much important for tape casting as its tolerance to small change in processing parameter (casting composition, drying rate, thickness etc.) is very less, therefore, generally produce defect tapes. Since, organic binders are less soluble in water, therefore, polymeric emulsion binders (colloidal dispersion of a polymer in water) are generally used for slurry formulation in water based tape casting. ${ }^{[2]}$ The viscosity of the aqueous slurry needs to be less for ensuring uniform mass flow which helps in maintaining uniform thickness after the casting. ${ }^{[25]}$ Pagnoux et al. ${ }^{[26]}$ reported aqueous tape casting of alumina powder using a combination of triton as dispersant and duramax acrylic emulsion as binder with deionized water for preparation of good quality tape. Doreau et al. ${ }^{[27]}$ tried acrylic emulsion

\section{Types of Slurry Preparation (Aqueous and Non- aqueous)}

The slurry preparation process depends on the types of solvent used. It may be aqueous or non-aqueous. The advantages of the aqueous system are (i) non-toxic, nonexplosive, non-flammable and environmental friendly, (ii) cost effective. ${ }^{[20-22]}$ However, some of the drawbacks of the tapes prepared by aqueous system are appearance of cracks, bubbles and other defects in the final product. The other process related defects are coagulating of the slip due to $\mathrm{pH}$ instability, froth formation during milling, early polymerization, tape fragility etc. Due to these issues, aqueous systems are not popular for mass production in industrial scale. However, the health issues and environmental concern associated with the organic solvents attracted the attention of researchers, industrialists to focus on water based tape casting in recent years. Commonly used components in aqueous tape casting of ceramic powders are presented in Table $\mathbf{2}^{[1,17,23]}$ binders and ammonium polyacrylate salt as dispersant for preparation of defect free alumina tapes by aqueous tape casting. Acrylic emulsion acts as both binder and plasticizer in water based tape casting is an added advantage over use of simple binder like PVA and methyl cellulose.

Non-aqueous solvent systems are used extensively in tape casting as the solvent evaporates easily from the cast slurry leaving a good quality tape. It also protects the powders absorbing moisture from the surrounding. However, extra provisions have to be made concerning its toxicity and inflammability. Because of the environmental and health considerations, efforts are being made to improve and promote aqueous tape casting as a viable alternative to organic tape casting. Commonly used 
components in non-aqueous tape casting of ceramic powders are presented in Table $3 .^{[1,14,28,29]}$.

Table 3. Commonly Used Components in Non-aqueous Tape Casting of Ceramic Powders [1, 14, 28, 29$].$

\begin{tabular}{|c|c|c|c|}
\hline Solvents & Dispersants & Binders & Plasticizers \\
\hline $\begin{array}{l}\text {-Acetone } \\
\text {-Ethyl alcohol } \\
\text { - Trichloro-ethylene } \\
\text { - Methyl ethyl ketone } \\
\text { - Benzene } \\
\text {-2-butanone } \\
\text { - Butanol } \\
\text { - Isopropyl alcohol } \\
\text { - Methyl isobutyl ketone } \\
\text { - Toluene } \\
\text {-Xylene } \\
\text { - Cyclohexanone }\end{array}$ & $\begin{array}{l}\cdot \text {-Fish oil } \\
\cdot \text { Corn oil } \\
\cdot \text { Phosphate ester (aliphatic } \\
\text { and aromatic) } \\
\cdot \text { Glycerol trioleate } \\
\text {-Dioleate } \\
\text { propylenediamine } \\
\text {-Castor oil } \\
\text {-Oleic acid } \\
\text {-Diethanolamine } \\
\text { - Triethanolamine }\end{array}$ & $\begin{array}{l}\text {-Poly(vinyl butyral) } \\
\text { - Cellulose acetate butyrate } \\
\text {-Poly (vinyl pyrrolidine) } \\
\text {-Poly (methyl methacrylate) } \\
\text {-Ethyl cellulose } \\
\text { - Nitrocellulose } \\
\text {-Polyacrylate esters } \\
\text {-Poly(vinyl chloride) } \\
\text {-Acrylic resins }\end{array}$ & $\begin{array}{l}\text { - Benzyl butyl phthalate } \\
\text {-Poly (ethylene glycol) } \\
\text { - Dibutyl phthalate } \\
\text { - Dioctyl phthalate } \\
\text { - Butyl stearate } \\
\text { - Butyl acrylate } \\
\text { - Benzyl phthalate } \\
\text { - Octyl phthalate } \\
\text { - Diethyl pthalate }\end{array}$ \\
\hline
\end{tabular}

A combination of tri-chloro ethylene and ethanol solvents, corn oil as dispersant, polyethylene glycol and benzyl butyl phthalate as plasticizers, poly vinyl butyral as binder works well for non-aqueous tape casting of alumina. ${ }^{[30]}$ Michalek et al. ${ }^{[31]}$ reported aqueous and non-aqueous tape casting of yttria stabilized zirconia powder. They observed water based slurry was associated with air bubbles, agglomerates, and presence of water even after drying of the tapes. Good quality and dense tape was obtained from nonaqueous composition.

\section{Tape Casting}

The homogeneous slurry is generally tape cast using a "doctor blade" technique ${ }^{[32,33]}$. The doctor's blade consists of a sharp-edged blade fixed to a platform such that a uniform clearance can be created by raising the blade to the specified thickness (in microns) with the help of micro-meter screws for getting the desired thickness of the tape. The filtered slurry is poured in front of the blade and the blade is drawn across the pool thus spreading the slurry in a uniformly thick layer over the substrate. There are two modes of operation - a moving blade-stationary carrier system (the doctor blade containing slurry moves over the carrier sheets) and a stationary blade - moving carrier system (the carrier sheets move below the doctor blade).

Tape casting is generally of continuous or noncontinuous type. Non continuous type of tape casting is generally followed in the laboratories while continuous type of tape casting is followed in industries for mass production. Generally, a tape casting machine consists of a flat bench parallel to the ground which supports a moving carrier made of a silicone coated "mylar" plastic sheet of few microns' thickness. Stainless steel is also commonly used as a carrier. The casting head (tank) and doctor blade are fixed at one end of the tape casting machine on the carrier. When the carrier moves it draws a layer of slurry depending on the gap with the doctor blade. In some cases, the doctor's blade is of moving type. One can select and fix the clearance between the mylar sheet and the doctors blade which ultimately decides the tape thickness. Similarly, one can select the casting speed with a speed control attached to an electric motor or a pneumatic system. The optimum casting speed can be determined based on the thickness of the tape being cast, the solvent system used and the length of the drying chamber. Casting speed is generally in the range of $15 \mathrm{~cm} / \mathrm{min}$ to $50 \mathrm{~cm} /$ min. After tape casting, the tapes are either dried in a dryer attached to it or it can be air-dried for few hours, specifically in case non-aqueous solvents are used. The typical process flow sheet for tape casting is presented in Figure 1.

\subsection{Drying of Tapes}

The drying of tapes involves several kinetic processes including evaporation, viscous deformation of the body or film and the flow of fluid in the pores and diffusion. The drying process of the suspensions takes place in three steps. In the first stage a constant drying rate is controlled by capillary migration of the solvent from inside the drying tape to the surface wherein the solvent evaporates. This helps slow settling of the ceramic powders on the carrier film. The loss of solvent is compensated by the contraction of the tape in the direction perpendicular to the casting plane. 
In the second drying stage, the process of solvent evaporation continues and the viscosity increases changing the fluid flow within the pores, therefore, the shrinkage rate doesn't follow the evaporation rate. Solidification started on the upper part of the tape and it restricts the movement of solvent to the surface, therefore, the drying takes place very slowly inside the tapes (third drying stage). During this stage, internal stresses occur that could lead to the cracking of the green tape.

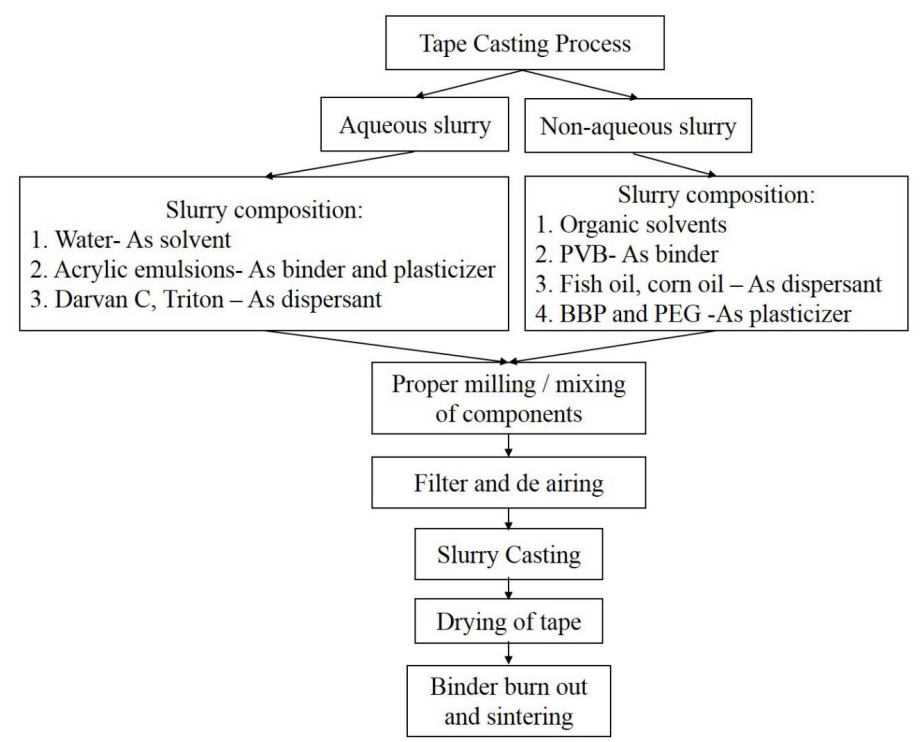

Figure 1. Typical Process Flow Sheet for Tape Casting

\subsection{Cracks in Tapes}

During the drying of the tapes, stresses develop due to shrinkage. If the stresses exceed the cohesion strength, it results in formation of cracks. The cracking is more commonly observed in water based systems than non-aqueous systems because the capillary forces are greater in the aqueous systems. Higher the thickness of the tapes, higher is the stress, therefore, higher is the probability of cracking. ${ }^{[34,35]}$

The cracks are of different types such as (i) "zipper bag"- The defects arise due to inhomogeneous mixing of the ceramic and binders leaving agglomerates of ceramic powder encased by the binders. ${ }^{[36]}$ It can be avoided by properly deflocculating the ceramic powder in the solvent before addition of the binder, (ii) "displacement effect"-cracks formed perpendicular to the casting direction. This occurs when the dispersant and binder are added together so that the ceramic particles are coated by the binders instead of the dispersant. In such cases, the amount of dispersant is more between the particles compared to the binder, therefore, the strength of the tape reduced, (iii) "crow's feet"- occurs due to insufficient de-airing of the slurry before tape casting, (iv) "networking" of cracks due to excess solvent which evaporates during drying leaving a network of cracks due to higher lateral stress in the tape (Figure 2).



Figure 2. Typical Networking of Cracks in PZT Tape due to Excess Solvent in the Slurry

Mori et al. ${ }^{[37]}$ studied the formation of cracks in aqueous tape casting of alumina green tapes by varying $\mathrm{pH}$ and binder content in the slurry. They observed defect free tapes at $\mathrm{pH}$ of 3.1, thereafter, the number of cracks increased with increase in $\mathrm{pH}$ of the slurry. The opposite trend was observed in binder variation study. The authors also observed that, there was a decrease in number of cracks with increase in stress relaxation rate of the tape. As per them, the drying stress should be released 
very fast for the slurry with higher stress relaxation rate which consequently produce crack free tapes. Shrinkage generally occurs in the thickness direction of the tape as there is less chance in other direction because the tape sticks to the carrier film/substrate. Martinez et al. ${ }^{[38]}$ reported that the ceramic phase was the main cause of stress development in initial stage but the binder contributes residual stress in the later stage. Similar observation was reported by Kiennemann et al. ${ }^{[39]}$ in aqueous tape casting of alumina.

\section{Fabrication of Multilayered Ceramics by Tape Casting}

The general fabrication of multilayered (ML) ceramics includes a number of steps such as (i) a defect free tape (ii) Cutting and electroding, (iii) Lamination and stacking, (iv) Binder-burnout and co-firing. A schematic diagram for fabrication of ML stack is presented in Figure 3. A good tape free from various defects, like pin holes, cracks etc. is very much essential for fabrication of multilayered stack. The defect free tapes were cut into a simple square or rectangular geometry depending on desired configuration of the final product. The cut tapes were then screen printed with electrode material and dried. Laminations of screen printed tapes were accomplished by applying pressure at temperature higher than glass transition temperature ( $\mathrm{Tg}$ ) of the binder. A good lamination reflects no borderline between the layers. Lamination pressure should be distributed equally, so that plastic deformation occurs similarly in all directions. This helps in getting good sintering of the laminate due to better shrinkage from all the sides. Generally, a pressure ranging from 1.4 $\mathrm{MPa}$ to $40 \mathrm{MPa}$ is applied for few second to few minutes to complete lamination process. ${ }^{[40,41]}$ The next stage is removal of organic components from the stack which is accomplished by very slow rate of heating of the sample in the temperature range of $250-650{ }^{\circ} \mathrm{C}$. At this stage the organic binders should fully expel from the laminate, otherwise little amount of carbon residue may hinder the complete densification process. The last step is sintering / co-firing of the laminate to get a fully dense product and is achieved by heating the sample at high temperature. An optimum temperature (generally 1100-1600 ${ }^{\circ} \mathrm{C}$ ) is applied based on the ceramic powder used to achieve good sintered density of the multilayered ceramics.

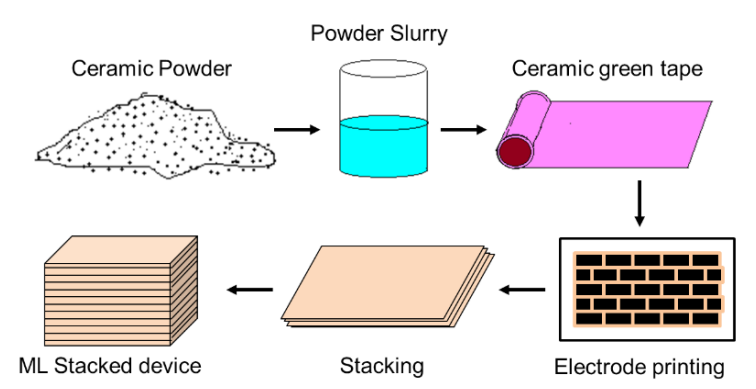

Figure 3. Schematic Diagram for Fabrication of ML Stack by Tape Casting Technique

\subsection{PZT Multilayered Stack}

Lead based piezoelectric materials such as PZT, PMN-PT and their modified compositions were very much suitable for piezoelectric and electrostrictive actuation application. ${ }^{[42-45]}$ In recent days, PZT multilayered (ML) stacks were frequently used for active vibration control, flutter control, cabin noise reduction etc. of aero structures. These ML stacks were fabricated by tape casting where very thin layers (80$120 \mu \mathrm{m}$ ) were used to reduce the driving voltage. The relation between applied voltage and thickness of each layer is governed by following equation:

$$
\Delta L=d_{33} . V . n---(1)
$$

Where, $\Delta L$ is the displacement, " $n$ " is the number of layers, $d_{33}$ is piezoelectric constant and $V$ is the applied voltage.

From the above equation it is observed that, an inverse relationship exists between the number of layers $(n)$ and the applied voltage $(V)$ if the displacement and $d_{33}$ are constant. As the number of layers increases in a specified height of the ML stack, the thickness of each layer consequently decreased which reduced the applied voltage. ${ }^{[46]}$ Generally, a driving voltage of $100 \mathrm{~V}$ is required for if the thickness of each layer is $\sim 100 \mu \mathrm{m}$.

A typical in-house fabricated PZT ML stack and its properties are presented below. Defect free PZT tape was prepared from a well optimized slurry using the PZT powder of composition $\mathrm{Pb}_{0.92} \mathrm{La}_{0.08}\left(\mathrm{Zr}_{0.60} \mathrm{~T}_{0.40}\right)$ $\mathrm{O}_{3}$. The density of green tape measured is $4.7 \mathrm{~g} / \mathrm{cc}$ (60.25\% theoretical density of PZT is $7.8 \mathrm{~g} / \mathrm{cc}$ ). A typical photograph of PZT tape is presented in Figure 4. The dried tape was cut, printed with Pt-electrode, stacked and iso-pressed at $40 \mathrm{MPa}$ for $20 \mathrm{~min}$ followed by binder burnout at $620{ }^{\circ} \mathrm{C}$ and co-firing/sintering of the stack at 
$1250{ }^{\circ} \mathrm{C}$. The photograph of sintered PZT multilayered stack is presented in Figure 5. The stack was poled at 20 $\mathrm{kV} / \mathrm{cm}$ and characterized.

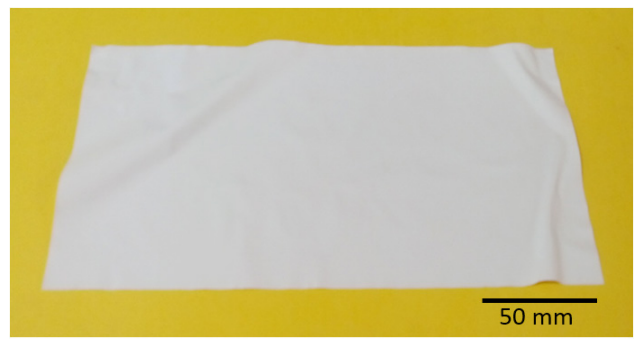

Figure 4. Photograph of PZT Tape $\left(250 \times 120 \mathrm{~mm}^{2}\right)$, Thickness: $100 \mu \mathrm{m}$

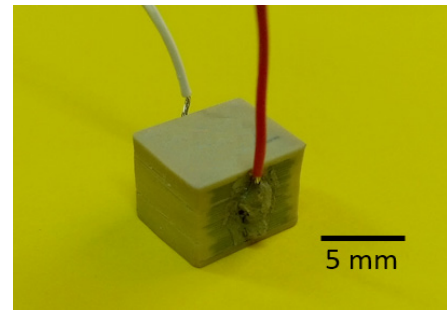

Figure 5. Photograph of PZT ML Stack after Aintering, Leveling and Poling

The displacement and block force of PZT ML stack was measure using a TF Analyzer, (AIXACCT, Germany). The hysteresis graph is presented in Figure 6. The remnant polarization $\left(P_{r}\right)$, saturation polarization $\left(P_{s}\right)$ and coercive field $\left(E_{c}\right)$ of the stack are $63 \mu \mathrm{C} / \mathrm{cm}^{2}, 225 \mu \mathrm{C} /$ $\mathrm{cm}^{2}, 3.5 \mathrm{kV} / \mathrm{cm}$ respectively. A typical displacement Vs. voltage graph is presented in Figure 7. The displacement measured for PZT ML stack is $6 \mu \mathrm{m}$ and block force 1500 $\mathrm{N}$ at $175 \mathrm{~V}$.

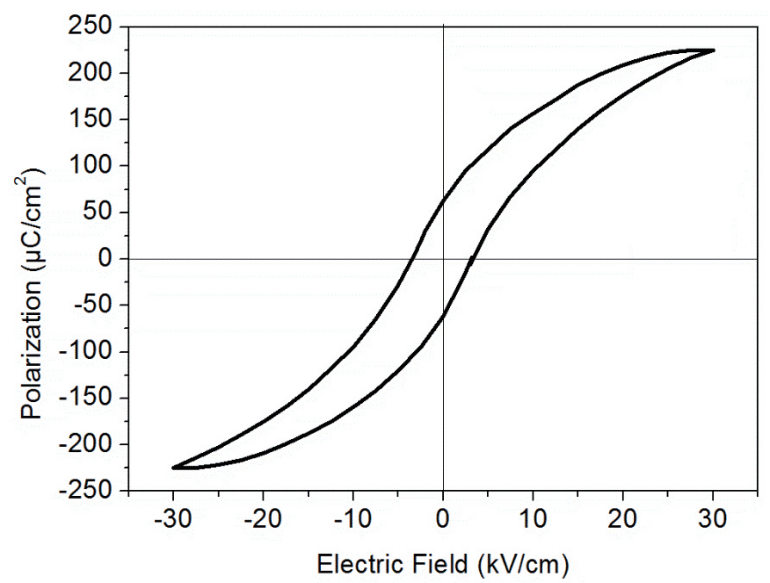

Figure 6. Hysteresis Loop of PZT ML Stack

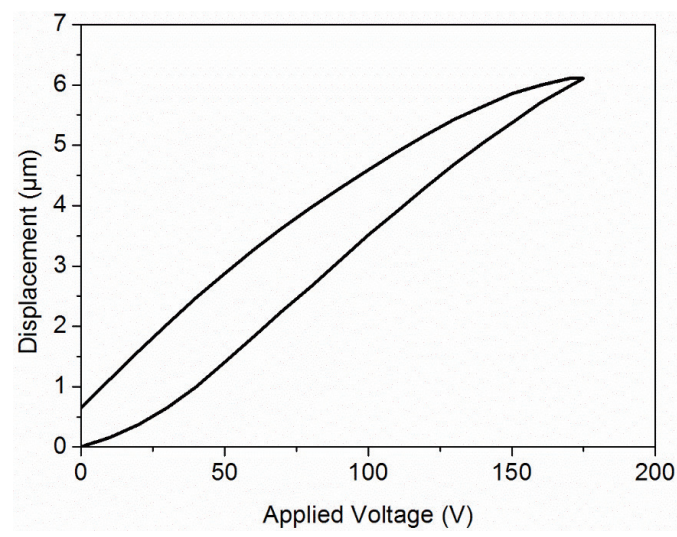

Figure 7. Typical Displacement and Polarization Curves of PZT ML Stack

\subsection{Lead Free Piezo ML Stack}

\subsubsection{Barium Strontium Zirconate Titanate (BSZT) Multilayered Stack}

Research on lead free piezoelectric materials is currently gaining momentum to replace lead based PZTs. Among them, modified barium titanates and sodium potassium niobates (KNN) materials are very much promising. ${ }^{[47,48]}$ In-house developed $\left(\mathrm{Ba}_{0.985}\right.$ $\left.\mathrm{Sr}_{0.015}\right)\left(\mathrm{Ti}_{0.98} \mathrm{Zr}_{0.02}\right) \mathrm{O}_{3}$ (BSZT) lead free piezo powders with piezoelectric constant $\left(d_{33}=330 \mathrm{pC} / \mathrm{N}\right)$ were used for fabrication of lead free piezo actuators. ${ }^{[49,50]}$ In the 1st stage the mixture of BSZT powder, solvents (Methyl Ethyl Ketone (MEK) and Ethyl alcohol), dispersant (Triton) and $\mathrm{ZrO}_{2}$ balls as grinding media were milled for $24 \mathrm{~h}$ on a roller mill. In the 2 nd stage required amount of binder (polyvinyl butyral, PVB), plasticiser and solvents were added and again milled for $48 \mathrm{hrs}$. The slurry was then tape cast on a silicone coated mylar sheet using tape casting equipment and tape thickness of $90 \mu \mathrm{m}$ was prepared (Figure 8).

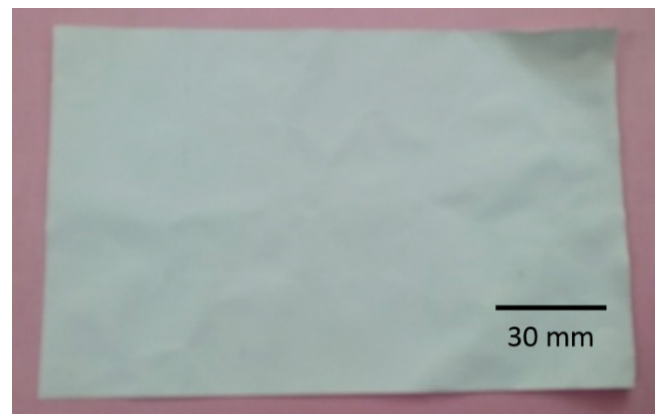

Figure 8. Photograph of Lead Free BSZT Tape (Size 130 x $90 \mathrm{~mm}^{2}$ ) 
The density of green tape was $\sim 71 \%$ of theoretical density. The tape was then dried, cut into required dimensions, screen printed with silver-palladium (AgPd) electrode paste and dried. The individual layers were then stacked, laminated, dried and iso-pressed. Binder burn out and co-firing of the stacks was carried out at $600{ }^{\circ} \mathrm{C}$ for $1 \mathrm{~h}$ and at $1050{ }^{\circ} \mathrm{C}$ for $1 \mathrm{~h}$ respectively. The stacks were levelled, terminal electrode and wires were drawn. The photograph of fabricated sintered BSZT ML stacks is shown in Figure 9 and their properties are presented in Table 4. Poling of the stacks was carried out at $30 \mathrm{kV} / \mathrm{cm}$ in a silicon oil bath for 45 minutes in the thickness direction and the properties were measured.

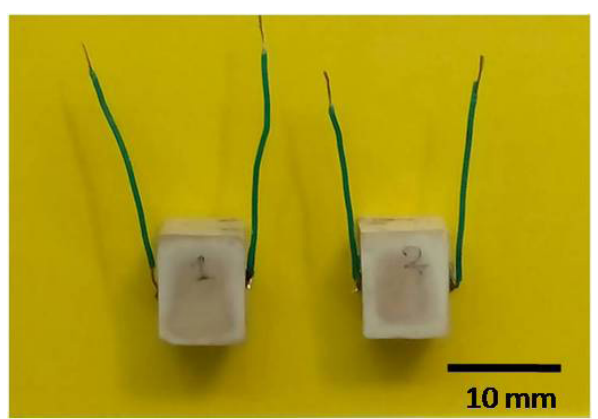

Figure 9. Photograph of BSZT ML Stack after Sintering and Poling

Table 4. Dimensions and Displacement of BSZT ML Stacks

\begin{tabular}{lcccc}
\hline Sample name & $\begin{array}{c}\text { Height } \\
(\mathbf{m m})\end{array}$ & $\begin{array}{c}\text { Length } \\
(\mathbf{m m})\end{array}$ & $\begin{array}{c}\text { Width } \\
(\mathbf{m m})\end{array}$ & $\begin{array}{c}\text { Displacement } \\
(\mathbf{n m})\end{array}$ \\
\hline BSZT-MLS-1 & 7.5 & 9.2 & 7.1 & 900 \\
BSZT-MLS-2 & 7.8 & 9.8 & 7.0 & 800 \\
\hline
\end{tabular}

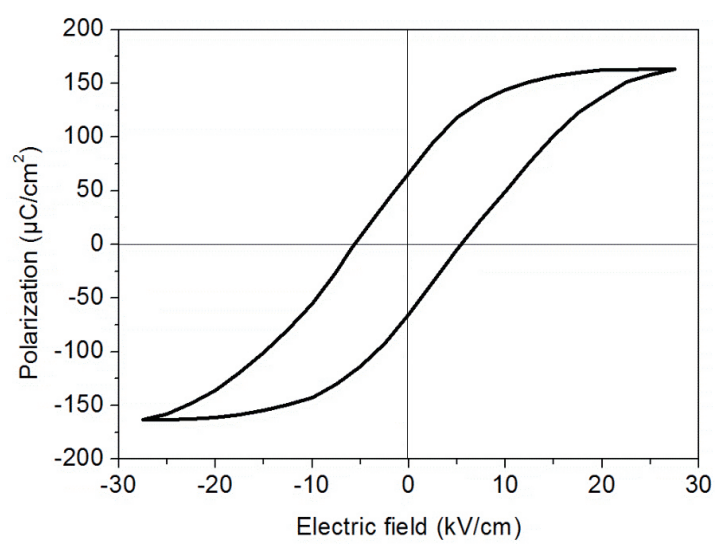

Figure 10. Typical Hysteresis Graph of BCZT-ML Stack-1

The hysteresis loop and displacement of BSZT ML stack was measured in the similar way as measured for
PZT ML stack. From the hysteresis graph (Figure 10) it is observed that remnant polarization $\left(P_{r}\right)$, saturation polarization $\left(P_{s}\right)$ and coercive field $\left(E_{c}\right)$ are $65 \mu \mathrm{C} / \mathrm{cm}^{2}$, $163 \mu \mathrm{C} / \mathrm{cm}^{2}, 4.3 \mathrm{kV} / \mathrm{cm}$ respectively. The displacement measured for BSZT ML stack is $885 \mathrm{~nm}$ (Figure 11).

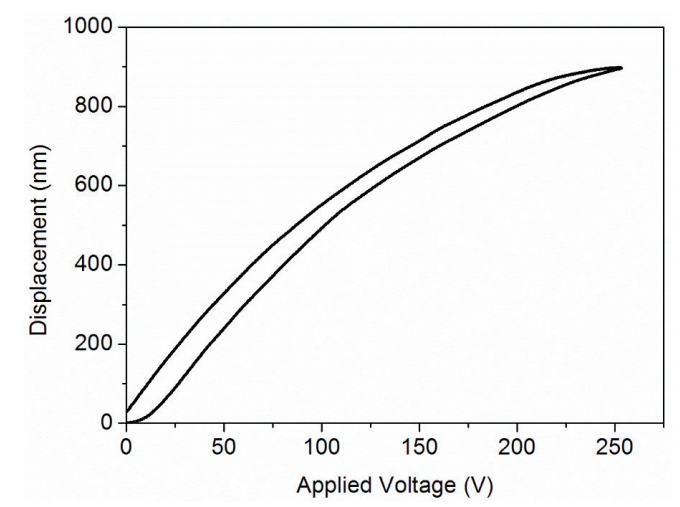

Figure 11. Typical Displacement Graph of BSZT-ML-1

Stack

\subsubsection{KNN based ML Stack}

Modified potassium sodium niobate (KNN) material is found to be one of the greatest contender for replacement of PZT for actuator application considering its piezoelectric properties comparable to PZT-5H grade. This environmental friendly lead free piezo material is safe for devices used in medical field as well as perspective biosensors application. But volatility of potassium and sodium oxides at high temperature generally restricts it fabrication. Therefore, researcher have tried a number of modifiers which can reduce the volatility of these oxides. Hussan et al. ${ }^{[51]}$ tried $\mathrm{NaBiZrO}_{3}$ modified $\mathrm{KNN}$ and observed there was an increase in piezoelectric properties and decrease in volatility of alkali metal oxide. The authors fabricated multilayered stacks (10 and 16 layered) using this materials and reported displacement of $2.2 \mu \mathrm{m}$ from 10 layered stack at $480 \mathrm{~V}$. Kawada et al. ${ }^{[52]}$ prepared Mn and excess $\mathrm{ZrO}_{2}$ doped $\mathrm{KNN}-\mathrm{CZ}$ (calcium zirconate) ceramics and fabricated multilayered stack out of it using Ni electrode material. The strain properties of the stack were found to be $1 / 3$ of the ML stack prepared by using Ag-Pd electrode. The author proposed that on reduction in thickness of dielectric layers and use of Ni electrode, the ML stack will provide similar displacement as observed in the case of ML stack with Ag-Pd electrode material. 


\subsubsection{BNT based Multilayered Stack}

Bismuth sodium titanate (BNT) based materials possess very good strain and are very much suitable for actuator application. A number of research reports were available for fabrication of bismuth sodium titanate based multilayered stacks. Krauss et al. ${ }^{[53]}$ prepared modified BNT ceramic tapes by aqueous tape casting and fabricated a multilayered stack of 50 active layers using Ag-Pd as internal electrode material. The stack produced temperature independent strain of $0.19 \%$ in the temperature range $25{ }^{\circ} \mathrm{C}$ to $150{ }^{\circ} \mathrm{C}$ which was attributed to the field induced phase transition. Generally, a key problem associated with fabrication of multilayered stack is development of mechanical stress due to different shrinkage behavior and thermal mismatch of electrode material and ceramic tape. Therefore, nano ceramic powders of same composition was sometimes mixed with electrode material to reduce these thermal mismatch. ${ }^{[44]}$ Nguyen, et al. ${ }^{[5]}$ fabricated BNT-BKT based multilayered stacks by following the same concept. The authors used lithium and tantalum modified BNT-BKT ceramic powders mixed with Ag-Pd electrode material as inner electrode for fabrication of the multilayered stack. The stack showed reduction in thermal mismatch and three times better strain properties compared to the stack prepared using without ceramic-metal composite electrode material. Ahn, et al. ${ }^{[5]}$ prepared $\mathrm{CuO}$ doped BNT-BKT ceramic tapes and fabricated the Ml stack. Addition of $\mathrm{CuO}$ reduced the sintering temperature of the BNT-BKT ceramics from $1150 \quad{ }^{\circ} \mathrm{C}$ to $950{ }^{\circ} \mathrm{C}$ thereby reduced the thermal mismatch and improved the strain properties.

Poor density and less piezoelectric properties are common problem associated with fabrication of multilayered piezo ceramics. A number of research has been carried out for improvement of density and piezoelectric properties. Plianaek et al ${ }^{[57]}$ fabricated $\mathrm{Pb}_{0.965} \mathrm{~K}_{0.03}\left[\mathrm{Nb}_{0.01}\left(\mathrm{Zr}_{0.53} \mathrm{Ti}_{0.47}\right)_{0.99}\right] \mathrm{O}_{3}$ piezoelectrc multilayered ceramic by tape casting and studied the effect of cover plate weight / load and duration of sintering on density and piezoelectric properties of the sample (size: 2 $\mathrm{x} 2 \mathrm{~cm}^{2}$ ). They observed that an alumina plate of weight $0.625 \mathrm{~g} / \mathrm{cm}$ and a dwelling time of $3 \mathrm{~h}$ during sintering was optimum for enhancement of density $(74.78 \%)$ and highest piezoelectric properties $(241 \mathrm{pC} / \mathrm{N})$. Similarly, Wattanasarn et al. ${ }^{[58]}$ tried to improve the piezoelectric properties of $\mathrm{Pb}_{0.976} \mathrm{~K}_{0.012} \mathrm{Bi}_{0.012}\left[\mathrm{Nb}_{0.01}\left(\mathrm{Zr}_{0.53} \mathrm{Ti}_{0.47}\right)_{0.99}\right] \mathrm{O}_{3}$ ceramic tape by following a three stage sintering process instead of conventional 2 step process. The observe that, the three step sintering process increased density of domain walls which was a major factor for improvement of piezoelectric properties.

\section{Recent Applications of Tape Casting Technique}

Thin tapes fabricated by tape casting technique serves a number of industries such as aerospace sector, microelectronics, ${ }^{[59,60]}$ energy sector (rechargeable battery, solid oxide fuel cells) and so on for numerous application. The green ceramics tapes were used in the preparation of many laminated components such as ceramic multilayer capacitors (CMC) and sensors, actuators ${ }^{[6]}$, multilayered electrode for $\mathrm{Li}$-ion batteries, solid oxide fuel cells (SOFC) ${ }^{[62,63]}$, laminated composites, microwave materials ${ }^{[64]}$, low temperature co-fired ceramics (LTCC) based miniature devices etc. for better performance.

\subsection{Solid State Lithium Ion Batteries}

Lithium ion battery is most affordable choice in rechargeable battery market for last 25 years due to its better charge density, reliability, easy handling, quick charging time etc. Researchers have been putting continuous effort to improve these properties of Li-ion batteries. One of the effort is to make the electrolyte in solid form and reduction in its thickness to accommodate a number of cells in a specific area thereby improving the charge density of the battery. Among many electrolytes, ceramic oxide electrolytes are found to be more suitable due to their higher thermal stability and larger lithium ion conduction compared to other electrolytes. The energy density of all solid Li-ion batteries depends on the thickness of ceramic electrolytes and its weight should be nearly equal to the weight of replaceable liquid electrolyte and separator. Therefore, to achieve high energy density of all-solid-state batteries, it requires solid state electrolytes as thin as possible.

In the initial stage, the electrolyte layers were prepared by simple cold or hot pressing method. Liu et al. ${ }^{[65]}$ attempted to fabricate solid electrolyte layer of thickness $300 \mu \mathrm{m}$ to $1 \mathrm{~mm}$ by simple pressing method. Subsequently, Jiang et al.$^{[66]}$ employed a phase-inversion method for fabrication of thin electrolyte layer $(<200 \mu \mathrm{m})$ 
which showed encouraging results on performance of the solid state battery. Other researchers also attempted a number of cumbersome techniques such as radio frequency (RF) and magnetron sputtering, pulsed laser deposition, atomic layer deposition, physical vapor deposition, chemical vapor deposition etc. for production of thin ceramic oxide films thickness ranging from 100 $\mathrm{nm}$ to $1 \mu \mathrm{m}$ on a substrate. ${ }^{[67,68]}$ Xiao et al. ${ }^{[69]}$ could able to fabricate such a thin layered solid state battery by sputtering technique, but its energy output was found very low. The process was very much time consuming and not cost effective for commercial use.

Out of many fabrication techniques, tape casting is found to be an efficient process for fabrication of free standing thin ceramic oxide electrolyte layers in a large scale. This technique is found to be promising for production of large scale solid state batteries suitable for immobile and handy power systems as well as for the development of full electric vehicles. The ceramic electrolyte layer should have good mechanical strength, good adaptability for electrolyte production and cell assembly for actual application. Lanthanum Lithium Titanate (LLTO) is a promising material for solid state electrolyte. Jiang et al. successfully prepared LLTO electrolyte film of thickness varying from $25-50 \mu \mathrm{m}$ by tapecasting technique and its performance on the battery assembly was found to be quite encouraging. ${ }^{[70]}$

Gamarra et al. ${ }^{[71]}$ prepared $\mathrm{Li}_{4} \mathrm{Ti}_{5} \mathrm{O}_{12}$ thick (250 $\mu \mathrm{m})$ electrodes for Li-ion batteries by tape casting. They reported that the volumetric capacity $(250 \mathrm{~mA} \mathrm{~h} /$ $\left.\mathrm{cm}^{3}\right)$ and areal capacity $\left(6-8 \mathrm{~mA} \mathrm{~h} / \mathrm{cm}^{2}\right)$ of this $250 \mu \mathrm{m}$ thick electrode were much higher compared to the as usual composite electrodes very much suitable for high performance batteries.

\subsection{Solid Oxide Fuel Cells (SOFC)}

Research on fuel cell technology is in full swing all over the world because of its considerable potential for power generation. This technology has advantage of producing more clean energy compared to conventional technologies. SOFC is a multilayered device having thin metallic and ceramic layers in an alternate fashion. The performance of the SOFC is mainly depends on the thermal properties, compatibility and stability of the used materials in the prevailing environment along with appropriate fabrication technology.

Tape casting is an encouraging technique for the extensive fabrication of self-supporting ceramic electrolyte films such as the porous anode for solid oxide fuel cells. Its thickness generally varied from 200 to $500 \mu \mathrm{m}$. Researchers also successfully prepared a self-supporting multilayered electrolyte film of $75 \mu \mathrm{m}$ thick by tape casting which had better interfacial surface area compared to the typical planar interface. ${ }^{[72,73]}$ Aqueous tape casting route is found to be more suitable for manufacture of anode and electrolyte films for SOFC application as it is simple, reduces environmental pollution and increases the production rate. ${ }^{[74]}$

\subsection{LTCC Application}

Tapecasting technique is the backbone of low temperature cofired ceramics (LTCC) processing. In LTCC technology, multilayered ceramics are generally fabricated in combination with a low melting highly conductive metal and co-firing at relatively low temperature $\left(1000{ }^{\circ} \mathrm{C}\right)$. This novel technology is used for fabrication of miniaturized, compact and light weight components embedded in the LTCC substrate (alumina/silicon wafer). This technology is very much attractive as it is comparatively easy to machine and generate complex three dimensional structures in the LTCC material in green stage. ${ }^{[75]}$

R\&D on LTCC technology is very much crucial for present days and future communication technologies. It has become an attractive technology for production of compact and light weight electronic components there by increased the speed as well as decreased the loss of signal transmission, increased the reliability of interconnects, functionality of mobile phones and data communication devices in many folds. This technology is already applied to circuit boards for main frame computers and is currently used for microwave applications. ${ }^{[76]}$ LTCC based technology is also used for fabrication of miniaturized sensor, actuator, accelerometers using very thin piezoelectric samples for high end aerospace and engineering applications. ${ }^{[77,78]}$

\subsection{Multilayered Ceramic Capacitor (MLCC)}

MLCCs are vital part of electronic gadgets such as smart phones, laptops, automotive vehicles, 
televisions etc. The role of MLCCs have now increased with the introduction of internet of things which is a convergence of multiple technologies. These MLCCs generally distribute and control the current flow in electronic circuit in a proper way for their better performance. ${ }^{[79]}$ The high capacitances of the MLCCs help in reduction of noise and error in the electronic systems. Miniaturization of MLCC is a key factor for better performance of the electronic systems. Tape casting technique play a crucial role for fabrication of very thin tapes $(<1 \mu \mathrm{m})$ of dielectric materials which consequently minimizes the component size.

MLCCs contains a number of layers with thin electrode layer alternatively stacked in parallel configuration. The capacitance of the MLCC is related inversely with the thickness of layer and directly proportional to the number of stacked layers, therefore, these two parameters became the key factor for increasing the capacitance of the device while keeping the area and the dielectric material constant. ${ }^{[80]}$

A number of processing parameters to be controlled for better productivity of MLCCs. For fabrication of very thin tape powder size $<300 \mathrm{~nm}$ is required, therefore, sophisticated processing routes such as wet chemical / sol-gel synthesis, high energy ball milling, other physical / chemical methods (sputtering, spark plasma deposition, chemical vapor deposition, spin coating) etc. were employed for generation of nano particle sized powders. ${ }^{[81]}$ Heat treatment / cofiring of the MLCCs at relatively low temperature with very slow heating rate helps in minimization of internal crack as well as infiltration of metal electrodes into the dielectric layers, thereby, increases the productivity and reliability of MLCCs. Firing in controlled atmosphere also helps in prevention of dielectric material reduction and oxidation of internal metallic electrodes. ${ }^{[82]}$

Barium titanate is a versatile material used for fabrication of MLCCs. It can be modified with various dopants tailoring the particular properties as per the application requirements. In recent days, research on low profile MLCCs (decreased thickness electronic chip) were in active stage as there is a huge requirement of such components in portable devices (tablet smart phones, high resolution camera module, semiconductor packaging etc.) where positioning of normal MLCCs are quite difficult. Research and production of embedded MLCCs (no external soldering) were also in full swing for further size reduction of devices with improved performance. ${ }^{[83]}$ Use of MLCCs in automotive applications also is in a great attention where high temperature stability, voltage stability, humidity, bending characteristics are the main properties of the device.

\subsection{Electro caloric devices}

An electro caloric device generally used for solid state caloric cooling where an isothermal entropy change or adiabatic temperature change occurs in the dielectric material with application or withdrawal of electric field. ${ }^{[84]}$ Generally, a high electric field is required to generate electro caloric effect in ferroelectric ceramics. Therefore, very thin layers of the dielectric material are required for reduction of the applied electric field and to increase the breakdown field $^{[85]}$. Tape casting technique plays a crucial role for fabrication of thin layers and such devices. MLCC structured dielectric material fabricated by tape casting is found to be more suitable for electrocaloric devices with enhanced performance and is extensively studied in last one decade ${ }^{[86]}$.

\subsection{Other Applications}

Tape casting technique is also quite promising for fabrication of transparent composite ceramics with waveguide architecture and with good laser performance. ${ }^{[87-89]}$ Reserachers also successfully prepared YAG based transparent multilayer ceramics by aqueous and non-aqueous tapecasting which showed better optical properties (i.e. transmittance $>84 \%$ ). ${ }^{[0]}$

PZT based thick film unimorphs were fabricated by tapecasting for energy harvesting applications. These unimorphs produced better energy output compared to the unimorphs prepared by conventional pressing method as these can effectively convert strong strain into electrical energy. ${ }^{[1-93]}$

Porous thin ceramics can be produced by tape casting with more control over porous structure compared to conventional powder-processing routes. Tape casting with combination of lamination stages is 
an effective method for engineering both micro and macrostructure of porous preform. ${ }^{[94]}$

\section{Conclusions}

Tape casting is a very useful technique for fabrication of thin sheets. The discovery and application of this technique lead to fabrication of various materials in the form of multi-layered stacks such as PZT sensors and actuators which are currently used extensively for various "smart" applications. Similarly, tape casting technique plays very crucial role in development of fuel cells, multi-layered capacitors, low temperature co-fired ceramics (LTCC) etc. However, the challenge always lies on preparation of defect free uniform tapes by optimizing preparation methodology of slurry preparation.

\section{Acknowledgements}

The authors sincerely thank NPMASS (Grant No. PARC\#3.7), CSIR FYPs (Grant.No. SIP-MT-04), DeitY (Grant no. 1(06)/2014-EMCD), New Delhi for the financial support.

\section{Conflicts of Interests}

The authors declare that they have no conflict of interest.

\section{References}

[1] Mistler RE. Tape casting: past, present, potential. Am Ceram Soc Bull. 1998; 77: 82-86.

[2] Mistler RE. Twiname ER. Tape casting: theory and practice, The American Ceramic Society, Westerville; 2000.

[3] Mistler RE. Tape casting: the basic process for meeting the needs of the electronic industry. Am Ceram Soc Bull. 1990; 69: 1022-1026.

[4] Howatt GN, Breckenridge RG, Brownlow JM. Fabrication of thin ceramic sheets for capacitors. J Am Ceram Soc. 1947; 30: 237-242.

[5] Howatt GN. Method of producing high-dielectric high-insulation ceramic plates, United States patent US 2,582,993. 1952 Jan 22.

[6] Park Jr JL. Manufacture of ceramics, United States patent US 2,966,719. 1963 Jan 3.

[7] Feng M, Feng Y, Zhang T, Li J, Chen Q, Chi Q, Lei Q. Recent advances in multilayer-structure dielectrics for energy storage application. Adv. Sci. 2021; 2102221, published online, https://doi. org/10.1002/advs.202102221

[8] Mistler RE, Shanefield DJ, Runk RB. Tape casting of ceramics, in ceramic processing before firing, edited by G. Y. Onoda Jr., L. L. Hench, John Wiley \& Sons, New York, 1978, pp.416-417.

[9] Bulatova R, Andersen KB, Kaiser A, Negra MD, Bahl CRH. Thickness control and interface quality as functions of slurry formulation and casting speed in side-by-side tape casting. J. Eur. Ceram. Soc. 2014; 34: 4285-4295.

[10] Jabbari M, Bulatova R, Tok AIY, Bahl CRH, Mitsoulis E, Hattel JH. Ceramic tape casting: A review of current methods and trends with emphasis on rheological behaviour and flow analysis. Mater Sci Eng B. 2016; 212: 39-61.

[11] Liu Z, Wang Y, Li Y. Combinatorial study of ceramic tape-casting slurries. ACS Comb Sci. 2012; 14: 205-210.

[12] Hotza D, Greil P. Review: aqueous tape casting of ceramic powders. Mater Sci Eng A. 1995; 202: 206-217.

[13] Shanefield DJ. Organic additives and ceramic processing, Kluwer Academic Publishers, Boston, 1995.

[14] Zhang J, Jiang D, Weisensel L, Greil P. Binary solvent mixture for tape casting of $\mathrm{TiO} 2$ sheets. J Eur Ceram Soc. 2004; 24: 147-155.

[15] Cannon WR, Morris J R, Milteslta KR. Dispersants for non-aqueous tape casting, in: J. B. Blum, W R. Cannon, editors, Advances in ceramics, Westerville, $\mathrm{OH}$, The American Ceramic Society, 1986, Vol. 19, pp. 161-174.

[16] Pagnoux C, Chartier T, Granja M, Doreau F, Ferreira JM, Baumard JF. Aqueous suspensions for tape-casting based on acrylic binders. J Eur Ceram Soc. 1998; 18: 241-247.

[17] Kristoffersson A, Roncari E, Galassi C. Comparison of different binders for water-based tape casting of alumina. J Eur Ceram Soc. 1998; 18: 2123-2131.

[18] Tasic N, Brankovic Z, Stanojevic ZM, Brankovic G. Effect of binder molecular weight on morphology of TiO2 films prepared by tape casting and their photovoltaic performance. Sci Sinter. 2012; 44: 365-372. 
[19] Immergut EH, Mark HF. Principles of plasticization, in: R. F. Gould, editors, Advances in Chemistry Series, plasticization and plasticizer processes, Washington, DC, Am Chem Soc. 1965, Vol. 48, pp. 6.

[20] Bitterlich B, Lutz C, Roosen A. Rheological characterization of water-based slurries for the tape casting process. Ceram Int. 2002; 28: 675 683.

[21] Lv Z, Zhang T, Jiang D, Zhang J, Lin Q. Aqueous tape casting process for SiC. Ceram Int. 2009; 35: 1889-1895.

[22] Navarro A, Alcock JR, Whatmore RW, Aqueous colloidal processing and green sheet properties of lead zirconate titanate (PZT) ceramics made by tape casting. J Eur Ceram Soc. 2004; 24: 1073 1076.

[23] Ren L, Luo X, Zhou H. The tape casting process for manufacturing low-temperature co-fired ceramic green sheets: A review. J Am Ceram Soc. 2018; 101: 3874-3889.

[24] Gurak NR, Josty PL, Thompson RJ. Properties and uses of synthetic emulsion polymers as binders in advanced ceramics processing. Am. Ceram. Soc. Bull. 2987; 66: 1495-1497.

[25] Nahass P, Rhine WE, Pober RL, Bowen HK, Robbins WL. A comparison of aqueous and nonaqueous slurries for tape casting, and dimensional stability in green tapes. Ceram. Trans. 1990;15: 355-364.

[26] Pagnoux C, Chartier T, Granja M, Doreau F, Ferreira JM, Baumarda JF. Aqueous suspensions for tape-casting based acrylic binders. J. Eur. Ceram. Soc. 1998; 18: 241-247.

[27] Doreau F, Tari G, Pagnoux C, Chartier T, Ferreira JM. Processing of aqueous tape-casting of alumina with acrylic emulsion binders. J. Eur. Ceram. Soc. 1998; 18: 311-321.

[28] Feng JH, Dogan F, Effects of solvent mixtures on dispersion of lanthanum-modified lead zirconate. J Am Ceram Soc. 2000; 83: 1681-1686.

[29] Minatto FD, Milak P, De Noni Jr A, Hotza D, Montedo ORK. Multilayered ceramic compositesA review. Adv Appl Ceram. 2015; 114: 127-138.

[30] Tok AIY, Boey FYC, Khor MKA. Tape casting of high dielectric ceramic substrates for microelectronics packaging, J. Mater. Eng.
Perform. 1999; 8: 469-472.

[31] Michalek M, Blugan G, Graule T, Kuebler J. Comparison of aqueous and non-aqueous tape casting of fully stabilized $\mathrm{ZrO}_{2}$ suspensions, Powder Technol. 2015; 274: 276-283.

[32] Lutz C, Roosen A. Wetting behavior of tape casting slurries on tape carriers. Ceram Trans. 1998; 83: 163-170.

[33] Runk RB, Andrejco M J. A precision tape casting machine for fabricating thin, organically suspended ceramic tapes. Am Ceram Soc Bull. 1975; 54: 199-200.

[34] Descamps M, Ringuet G, Leger D, Thierry B. Tape-casting: relationship between organic constituents and the physical and mechanical properties of tapes. J Eur Ceram Soc. 1995; 15: 357-362.

[35] Yu M, Zhang J, Li X, Liang H, Zhong H, Li Y, Duan Y, Jiang DL, Liu X, Huang Z. Optimization of the tape casting process for development of high performance alumina ceramics. Ceram Int. 2015; 41: 14845-14853.

[36] Blugan G, Morawa K, Koebel S, Graule T, Kuebler J. Development of a tape casting process for making thin layers of $\mathrm{Si}_{3} \mathrm{~N}_{4}$ and $\mathrm{Si}_{3} \mathrm{~N}_{4}+\mathrm{TiN}$. J. Eur. Ceram. Soc. 2007; 27: 4789-4795.

[37] Mori T, Yamada T, Tanaka T, Katagiri A, Tsubaki J. Effect of slurry properties on the crack formation in ceramic green sheets during drying. J. Ceram. Soc. Jpn. 2006; 114: 823-828.

[38] Martinez CJ. Lewis JA. Rheological, structural, and stress evolution of aqueous $\mathrm{Al}_{2} \mathrm{O}_{3}$ : latex tapecast layers. J. Am. Ceram. Soc., 2002; 85: 24092416.

[39] Kiennemann J, Chartier T, Pagnoux C, Baumard JF, Huger M, Lamerant JM. Drying mechanisms and stress development in aqueous alumina tape casting, J. Eur. Ceram. Soc. 2005; 25: 1551-1564.

[40] Panda PK, Sahoo B, Raja S, Vijaya Kumar MP, Shankar V. Electromechanical and dynamic characterization of in-house fabricated amplified piezo actuator. Smart Mater Res. 2012; 2012: 203625.

[41] Sahoo B, Panda PK. Fabrication of simple and ring-type piezo actuators and their characterization. Smart Mater Res. 2012; 2012: 821847.

[42] Uchino K. Ceramic actuators: principles and 
application. MRS Bulletin. 1993; 18: 42-48.

[43] Sahoo B, Panda PK. Effect of $\mathrm{CeO}_{2}$ concentration on dielectric, ferroelectric and piezoelectric properties of PMN-PT (67/33) composition. J Mater Sci. 2007; 42: 4745-4752.

[44] Zarnik MS, Kosec M. Pb( $\left.\mathrm{Mg}_{1 / 3} \mathrm{Nb}_{2 / 3}\right) \mathrm{O}_{3}-\mathrm{PbTiO}_{3}$ (PMN-PT) material for actuator applications. Smart Mater Res. 2011: 2011; 452901.

[45] Sahoo B, Panda PK. Ferroelectric, dielectric and piezoelectric properties of $\left.\mathrm{Pb}_{1-\mathrm{x}} \mathrm{Cex}\left(\mathrm{Zr}_{0.60} \mathrm{Ti}_{0.40}\right) \mathrm{O}_{3}\right], 0$ $\leqslant \mathrm{x} \leqslant 0.08$. J Mater Sci. 2007; 42: 9684-9688.

[46] Takahasi S, Yano T, Fukui I, Sato E. Multilayer piezoelectric ceramic actuator with varying thickness layers. Jpn J Appl Phys. 1985; 24: 206208.

[47] Politova ED, Golubko NV, Kaleva GM, Mosunov AV, Sadovskaya NV, Stefanovich SY, Kiselev DA, Kislyuk AM, Chichkov MV, Panda PK. Structure, ferroelectric and piezoelectric properties of KNNbased perovskite ceramics. Ferroelectrics. 2019; 538: 45-51.

[48] Politova ED, Golubko NV, Kaleva GM, Mosunov AV, Sadovskaya NV, Stefanovich SY, Kiselev DA, Kislyuk AM, Panda PK. Processing and characterization of lead-free ceramics on the base of sodium-potassium niobate. J Adv Dielectr. 2018; 8: 1850004.

[49] Chandraiah M, Panda PK. Effect of SrO on piezoelectric, dielectric and ferroelectric properties of $\left(\mathrm{Ba}_{1-\mathrm{x}} \mathrm{Sr}_{\mathrm{x}}\right)\left(\mathrm{Ti}_{0.98} \mathrm{Zr}_{0.02}\right) \mathrm{O}_{3}$ lead free piezoceramics. J Mater Sci: Mater Electron. 2015; 26: 3143-3147.

[50] Chandraiah M, Panda PK. Effect of dopants $\left(\mathrm{A}=\mathrm{Mg}^{2+}, \mathrm{Ca}^{2+}\right.$ and $\left.\mathrm{Sr}^{2+}\right)$ on ferroelectric, dielectric and piezoelectric properties of $\left(\mathrm{Ba}_{1-\mathrm{x}} \mathrm{A}_{\mathrm{x}}\right)$ $\left(\mathrm{Ti}_{0.98} \mathrm{Zr}_{0.02}\right) \mathrm{O}_{3}$ lead-free piezo ceramics. Ceram Int. 2915; 41: 8040-8045.

[51] Hussain F, Khesro A, Lu Z, Wang G, Wang D. Lead free multilayer piezoelectric actuators by economically new approach. Front. Mater. 2020; 7 : 87.

[52] Kawada S, Kimura M, Higuchi Y, Takagi H. (K, Na) $\mathrm{NbO}_{3}$-based multilayer piezoelectric ceramics with nickel inner electrodes. Appl. Phys. Exp. 2009; 2: 111401.

[53] Krauss W, Schütz D, Naderer M, Orose D, Reichmann K. BNT-based multilayer device with large and temperature independent strain made by a water-based preparation process. J. Eur. Ceram. Soc. 2011; 31: 1857-1860.

[54] Reichmann K, Feteira A, Li M. Bismuth sodium titanate based materials for piezoelectric actuators. Materials 2015; 8: 8467-8495.

[55] Nguyen VQ, Kang JK, Han HS, Lee HY, Jeong SJ, Ahn CW, Kim IW, Lee JS. Bi-based leadfree ceramic multilayer actuators using $\mathrm{AgPd}$ $\left(\mathrm{Na}_{0.51} \mathrm{~K}_{0.47} \mathrm{Li}_{0.02}\right)\left(\mathrm{Nb}_{0.8} \mathrm{Ta}_{0.2}\right) \mathrm{O}_{3}$ composite inner electrodes. Sens. Actuators A. 2013; 200: 107-113.

[56] Ahn CW, Kim HS, Woo WS, Won SS, Seog HJ, Chae SA, Park BC, Jang KB, Ok YP, Chong HH, Kim IW. Low temperature sintering of $\mathrm{Bi}_{0.5}(\mathrm{Na}$, $\mathrm{K})_{0.5} \mathrm{TiO}_{3}$ for multilayer ceramic actuators. J. Am. Ceram. Soc. 2015; 98: 1877-1883.

[57] Plianaek P, Bureemat W, Sittkankaew M, Thammajinda M, Hemadhulin O, Wattanasarn H. Sintering process for tape casting of piezoelectric ceramics, Ferroelectr. 2019; 552: 132-139.

[58] Wattanasarn H, Hemadhulin O, Ngennam T, Saenklan S. Enhanced piezoelectric properties of $\mathrm{Pb}_{0.976} \mathrm{~K}_{0.012} \mathrm{Bi}_{0.012}\left[\left(\mathrm{Zr}_{0.53} \mathrm{Ti}_{0.47}\right)_{0.99} \mathrm{Nb}_{0.01}\right]_{3}$, ceramic tape casting by three step sintering. Integr. Ferroelectr. 2021; 214: 158-165.

[59] Tok AIY, Boey FYC, Khor MKA. Tape casting of high dielectric ceramic composite substrates for microelectronics application. J Mater Engg Perform. 1999; 8: 469-472.

[60] Wang L, Tang G, Xu ZK, Preparation and electrical properties of multilayer $\mathrm{ZnO}$ varistors with water-based tape casting. Ceram. Int. 2009; 35: 487-492.

[61] Panda PK, Sahoo B. PZT and lead-free piezo ceramics for aerospace and energy applications, in: Y. Mahajan, R. Johnson, editors, Handbook of Advanced Ceramics and Composites, Springer Nature Switzerland AG 2020, pp. 1081-1103.

[62] Baquero T, Escobar J, Frade J, Hotza D. Aqueous tape casting of micro and nano YSZ for SOFC electrolytes. Ceram Int. 2013; 39: 8279-8285.

[63] Timakul P, Jinawath S, Aungkavattana P. Fabrication of electrolyte materials for solid oxide fuel cells by tape-casting. Ceram Int. 2008; 34 : 867-871.

[64] Thomas D, Abhilash P, Sebastian MT. Casting and characterization of $\mathrm{LiMgPO}_{4}$ glass free LTCC 
tape for microwave applications. J Eur Ceram Soc. 2013; 33: 87-93.

[65] Liu T, Zhang Y, Zhang X, Wang L, Zhao SX, Lin YH, Shen Y, Luo J, Li L, Nan CW. Enhanced electrochemical performance of bulk type oxide ceramic lithium batteries enabled by interface modification. J Mater Chem A. 2018; 6: 46494657.

[66] Jiang Z, Xie H, Wang S, Song X, Yao X, Wang H. Perovskite membranes with vertically aligned micro channels for all-solid-state lithium batteries. Adv Energy Mater. 2018; 8: 1801433.

[67] Imanishi N, Hasegawa S, Zhang T, Hirano A, Takeda Y, Yamamoto O. Lithium anode for lithium-air secondary batteries. J Power Sources. 2008; 185: 1392-1397.

[68] Loho C, Djenadic R, Bruns M, Clemens O, Hahn H. Garnet-type $\mathrm{Li}_{7} \mathrm{La}_{3} \mathrm{Zr}_{2} \mathrm{O}_{12}$ solid electrolyte thin films grown by CO2-laser assisted CVD for allsolid-state batteries. J Electrochem Soc. 2017; 164: A6131-A6139.

[69] Xiao DL, Tong J, Feng Y, Zhong GH, Li WJ, Yang CL. Improved performance of all-solid-state lithium batteries using LiPON electrolyte prepared with Li-rich sputtering target. Solid State Ionics. 2018; 324: 202-206.

[70] Jiang Z, Wang S, Chen X, Yang W, Yao X, Hu $X$, Han Q, Wang H. Tape-casting $\mathrm{Li}_{0.34} \mathrm{La}_{0.56} \mathrm{TiO}_{3}$ ceramic electrolyte films permit high energy density of lithium-metal batteries. Adv Mater. 2020; 32: 1906221.

[71] Gamarra C, Sotomayor ME, Bucheli W, Amarilla JM, Sanchez JY, Levenfeld B, Varez A. Tape casting manufacturing of thick $\mathrm{Li}_{4} \mathrm{Ti}_{5} \mathrm{O}_{12}$ ceramic electrodes with high areal capacity for lithiumion batteries. J. Eur. Ceram. Soc. 2021; 41: 1025 1032

[72] Cologna M, Sglavo VM, Bertoldi M. Sintering and deformation of solid oxide fuel cells produced by sequential tape casting. Int J Appl Ceram Technol. 2010; 7: 803-813.

[73] Jang WS, Hyun SH, Kim SG. Preparation of YSZ/ YDC and YSZ/GDC composite electrolytes by the tape casting and sol-gel dip-drawing coating method for low-temperature SOFC. J Mater Sci. 2002; 37: 2535-2541.

[74] Tiffee EI, Weber A, Herbstritt D. Materials and technologies for SOFC components. J Eur Ceram Soc. 2001; 21: 1805-1811.

[75] Jurkow D, Golonka L. Cold chemical lamination: new bonding technique of LTCC green tapes. Int. J Appl Ceram Technol. 2010; 7: 814-820.

[76] Imanaka Y. Multilayered low temperature cofired ceramics (LTCC) technology, Springer USA, 2005 .

[77] Golonka L. Technology and applications of low temperature cofired ceramic (LTCC) based sensors and microsystems. Bull Pol Acad Sci-Tech. 2006; 54: 223-233.

[78] Jurkow D, Dazbrowski A, Golonka L, Zawada T. Preliminary model and technology of piezoelectric low temperature co-fired ceramic (LTCC) uniaxial accelerometer. Int J Appl Ceram Technol. 2013; 10: 395-404.

[79] Hao H, Liu M, Liu H, Zhang S, Shu X, Wang T, Yao Z, Cao M. Design, fabrication and dielectric properties in core-double shell $\mathrm{BaTiO}_{3}$-based ceramics for MLCC application, RSC Adv. 2015; 5: 8868-8876.

[80] Hong K, Lee TH, Suh JM, Yoon SH, Jang HW. Perspectives and challenges in multilayer ceramic capacitors for next generation electronics. J. Mater. Chem. C. 2019; 7: 9782-9802.

[81] Pithan C, Hennings D, Waser R. Progress in the synthesis of nanocrystalline $\mathrm{BaTiO}_{3}$ powders for MLCC. Int. J. Appl. Ceram. Technol. 2005; 2: $1-14$.

[82] Zhang Y, Wang X, Kim JY, Tian Z, Fang J, Hur $\mathrm{KH}$, Li L. High performance $\mathrm{BaTiO}_{3}$-based BME-MLCC nano powder prepared by aqueous chemical coating method. J. Am. Ceram. Soc. 2012; 95:1628-1633.

[83] Kishi H, Mizuno Y, Chazono H. Base-metal electrode-multilayer ceramic capacitors: past, present and future perspectives. Jpn. J. Appl. Phys. 2003; 42: 1-15.

[84] Liu H. Electrocaloric effect enhanced thermal conduction of a multilayer ceramic structure. Chin. Phys. B. 2020; 29: 087701.

[85] Faye R, Strozyk H, Dkhil B, Defay E. Large heat flux in electrocaloric multilayer capacitors. J. Phys. D: Appl. Phys. 2017; 50: 464002.

[86] Nair B, Usui T, Crossley S, Kurdi S, GuzmanVerri G G, Moya X, Hirose S, Mathur N D. Large 
electrocaloric effects in oxide multilayer capacitors over a wide temperature range. Nature 2019; 575 : 468-472.

[87] Belon R, Boulesteix R, Geffroy PM, Maitre A, Salle C, Chartier T. Tape casting of multilayer YAG-Nd:YAG transparent ceramics for laser applications: study of green tapes properties. J. Eur. Ceram. Soc. 2019; 39: 2161-2167.

[88] Ma C, Tang F, Lin H, Chen W, Zhang G, Cao Y, Wang W, Yuan X, Dai Z. Fabrication and planar waveguide laser behavior of YAG/Nd:YAG/ YAG composite ceramics by tape casting. J Alloy Compd. 2015; 640: 317-320.

[89] Gabrielyan NT, Merkle LD, Kupp ER, Messing GL, Dubinskii M. Efficient resonantly pumped tape cast composite ceramic Er:YAG laser at 1645 nm. Opt Lett. 2010; 35: 922-924.

[90] Ba X, Li J, Pan Y, Zeng Y, Kou H, Liu W, Liu J, Wua L, Guo J. Comparison of aqueous and nonaqueous-based tape casting for preparing YAG transparent ceramics, J. Alloy. Compd. 2013; 577:
228-231.

[91] Panda PK, Sahoo B, Chandraiah M, Sreekumari R, Bindu M, Ramakrishna J, Kiran P. Piezoelectric energy harvesting using PZT bimorphs and multilayered stacks, J Electron Mater. 2015; 44: 4349-4353.

[92] Jeon CJ, Hwang HN, Jeong YH, Yun JS, Nam JH, Cho JH, Paik JH, Lim JB, Nahm S, Kim ES. High energy-density $0.72 \mathrm{~Pb}\left(\mathrm{Zr}_{0.47} \mathrm{Ti}_{0.53}\right)$ $\mathrm{O}_{3}-0.28 \mathrm{~Pb}\left[\left(\mathrm{Zn}_{0.45} \mathrm{Ni}_{0.55}\right)_{1 / 3} \mathrm{Nb}_{2 / 3}\right] \mathrm{O}_{3}$, thick films fabricated by tape casting for energy harvesting device applications. J Korean Phys Soc. 2013; 63: 1772-1776.

[93] Panda PK, Sahoo B, Ramakrishna J, Bindu M, Prasad Rao DSD. Recent studies on vibrational energy harvesting of PZT materials. Mater Today Proc. 2018; 5: 21512-21516.

[94] Corbin SF, Apte PS. Engineered porosity via tape casting, lamination and the percolation of pyrolyzable particulates, J Am Ceram Soc. 1999; 82: 1693-1701. 